\title{
Islamic Theological Literature of the Salafi Sect in the Modern Tatarstan
}

\author{
Damir A. Shagaviev ${ }^{1} \&$ Venera N. Khisamova ${ }^{1}$ \\ ${ }^{1}$ Kazan (Volga Region) Federal University, Kazan, Russia \\ Correspondence: Damir A. Shagaviev, Kazan (Volga Region) Federal University, 420008, Kazan, \\ Kremlyovskaya Street, 18, Russia. E-mail: saiddamir@mail.ru
}

Received: June 15, 2015 Accepted: June 24, 2015 Online Published: June 30, 2015

doi:10.5539/jsd.v8n7p83 URL: http://dx.doi.org/10.5539/jsd.v8n7p83

\begin{abstract}
The urgency of the problem under investigation is due to the fact that the Salafists, modern followers of Shaykh Ibn Taymiyy and Ibn 'Abdalvahhab, today are also presented in Tatarstan, which in turn affects in a certain way on the religious situation in the region. The purpose of this article is to identify and analyze patterns of outstanding Salafi doctrinal literature in modern Tatarstan. The leading approach to the study of this problem is a systematic and comparative analysis which allows to carry out islamic study on the topic. In this article the concept of "Salafis," is revealed, the Salafi Muslims categories, their theological differences with the traditional Muslim sects, the analysis of the Islamic Salafi doctrinal literature authors, published in today's Tatarstan are described. The results presented in the article indicate wide circulation of Salafi literature in Tatarstan in recent years, various types of such literature, and how its content is contrary to the theological tradition of the local Hanafi Muslim. The article may be useful in the study of the religious situation in the regions of Russia at the moment.
\end{abstract}

Keywords: Islam, Theology, Salafism, Doctrine, Religious Literature, Tatarstan

\section{Introduction}

Tatarstan is not aloof from the processes taking place in the world. Those trends are observed among the Muslims of other countries and regions affected in one way or another local Muslims as well. There are new Islamic movements and groups, which are non-traditional for Muslims of Tatarstan. Today, it can be argued, of course, given the low religiosity in the country, that the so-called Salafi ideology (salyafiyyia) is the most significant and widely-spread one among Muslims. The believers, who do not just practice Islam at the level of faith and try to observe his precepts and rituals are considered to be Muslims keeping the faith.

What is meant here are not strictly structured jamaats (groups) that exist in the modern world among Salafists, but the theological thought direction or a new orientation (madhhab). It is more correct to call it the doctrine taymizm and his followers taymits or Wahhabits, respectively, in honor of the of the medieval founder Ibn Taymiyya (d. 1328), or a posterior follower of Ibn 'Abdalvahhab (d. 1792). Both Sheikh Ibn Taymiyyah and Ibn 'Abdalvahhab were originally hanbalizm representatives, of the fourth Sunni Madhab. As a rule, Salafi sheikhs themselves see the beginning of their teaching in the views of Imam Ahmad ibn Hanbal. Scientists of traditional Sunni sects argue that the Salafis Ibn Hanbal contradict the doctrine, like the doctrine of the other three Sunni imams. However, in matters of fiqh modern Salafis are more closer to the Hanbalit school.

Most Sunni theologians approve of such terms, as well as the concept of "Ash'aris" by Imam al-Ash'ari"m and "maturidity" by Imam al-Maturidi or "Hanafi" by Imam Abu Hanifa, "Shafi'ites" of Imam Al-Shafi'i, etc. And the term "salyafiyya", on the contrary, considers innovation in Islam unacceptable (al-Buty, 2008), leading to a split and discord in the ranks of Muslim believers, because calling themselves thus they claim that they only follow the tradition of the righteous ancestors (in Arabic "Salaf"), that is the way the first three generations of Muslims (Shagaviev, 2015). But some Islamic scholars still insist on the concept of "Salafi Islam» (Qadhi, 2013). In this article, we use the narrow meaning of "Salafis ", meaning it is our contemporary Wahhabi.

In the traditional (Sunni) Islam it is believed that all the Sunnis follow the tradition of the righteous ancestors (Salaf). Sunnis have one teaching in the basic matters of faith, so they are called by the term Ahl al-Sunnah wal-Jama'ah (people of Sunnah and consensus of the community), and in the branches of faith matters they are 
Ash'aris or maturidits, in questions of religious practice they are called Hanafi, Maliki, Shafi'is and Hanbali. Interestingly, one of the modern Wahhabit authorities, the former mufti of Saudi Arabia, the late Sheikh Bin Baz, in their fatwas, expressed a very positive attitude to the title "vahhabiyya" considering him known and blessed, pointing to the dignity of faith. However, other Saudi sheikhs and all many wahhabis or taymits prefer to be called, either Salafis or muvahhids (monotheists), or, in extreme cases, Hanbalits. For researchers of Islam, the Wahhabis and taymits are one of the directions of Islam, and their name does not have a negative connotation. The theory was developed in this direction by Imam Ibn Taymiyyah, and a practical embodiment of this trend was already due to Ibn 'Abdalvahhab, of course, given its alliance with the family of Sa'ud in Najd.

Ordinary Muslims who came under the influence of sermons taymits or read their books, and called Asharites maturiditov - misguided Muslims, and in the worst case, remove them from Islam. This is in spite of the formation of traditional Islamic literature rumors, which says the opposite. As one of the large modern scholar of Islam, MS Ramadan al-Buta "Ash'arites and maturidity are flesh and blood of Ahl al-Sunnah wal-Jama'ah, and a large majority (al-Sawad al-a'zam) that the Messenger of Allah (s.'a.w.) commanded to follow» (al-Buti, 2008).

What is the difference of the Salafis (Wahhabis or Taymits) from ordinary Sunnis in terms of theology? To be brief, we can say that the differences of ordinary Sunnis from those who call themselves Salafis concern mainly three issues (al'-Buty, 2008), which may have a branch. It is a question of attributes of Allah, i.e. the question of the interpretation and understanding of monotheism (tawhid), then the problem of innovations (bid'at), and finally, the attitude to Sufism. These questions might remain theoretical and do not go beyond the pages of theological treatises, as, in principle, it was before. But real life, especially the events of the last few centuries, manifests these disagreements on another level. Inadequate (radical) understanding of these issues today leads to religious extremism, which in turn leads to more disastrous consequences, aggression and murder. Conversely, if you settle the conflict between the taymits and Asharites and Maturidits, all Sunnis can breathe freely and solve the urgent problems of the Muslim community. We have mentioned the most significant theological differences, meaning ordinary or moderate Salafis, who are said to represent a risk group of the majority of Salafis. If we consider the extreme Salafis and jihadis, then we go to the next level of theological differences, mainly related to issues of war and peace between Muslims and infidels, and accusations of infidelity issues.

The most important issue for Muslims is a question of monotheism (tawhid). And here come the accusations of polytheism (shirk), which lead to conflict and charges of apostasy (irtidad). Apostasy, if it happened in a clear and public form, from the point of view of Islam is one of the greatest sins which is punishable by death, by analogy with treason in the presence of the Institute of the caliphate, or Islamic state. But the accused and convicted of this can repent before Sharia judge and avoid punishment. In the absence of the Institute of Islamic state, some radicals are trying to punish the apostates themselves, sometimes not caring about the opportunity for the accused to repent. The charge of polytheism is true for both sides. It may be encountered among traditional Muslims as well, although much less frequently. Extreme or those professing views of individual Sunni scholars among Ash'aris and maturidits consider Salafis (Wahhabis) to be infidel because they worship an object at the sky, that is, in their view, they commit idolatry (shirk).

All kinds of Salafists have the same doctrinal foundations (Qadhi, 2013), so they are called taymits or Wahhabis, and guided to the same authority, i.e. they use the same books and sources. For example, they all recognize Ibn Taymiyyah, his student Ibn al-Qayyim, later taymit sheikhs, such as Ibn 'Abdalvahhab. The difference is due to the fact that certain groups have some other modern authorities, giving new interpretations and having different approaches to certain Sharia issues. Sometimes they differ in the way that they take some decisions and fatwas, and the others for some reason reject the latter.

Extreme taymits accuse Ibn Base, Nasir al-Albani and other modern taymit authorities of murdzhiizm. They call the latter court theologians and at best they take their earlier fatwa, or sharia opinions not related to faith and jihad. In the worst case they accuse them of infidelity (make takfir). Murdzhiizm in its basis is the teachings of some early Muslims, abstaining from supporting any of the rival groups of Muslims in the power issue. Late murdzhiit claimed that sin is in no way affects the position of believers and that believers are guaranteed paradise without purification in the form of punishment, despite their fall from grace (Shagaviev, 2007). Recent Salafis use this term mainly in relation to those theologians who are not adequately, in their opinion, apply the charge of infidelity against Muslim rulers and their subordinates.

Accordingly, the moderate Salafis accuse modern extreme Salafis of misbelieve, calling them new kharijites or kutubits as they absorbed the ideas of the Egyptian Islamic thinker and political figure, ideologist of the organization "Muslim Brotherhood", Sayyid Qutb (d. In 1966). By the way, the latter are even punishable by law in Saudi Arabia. The fact is that kharijites are one of the earliest sects in Islam. They became known for their 
extreme brutality against their opponents. They led guerrilla operations on the territory of the caliphate, killing Muslims who do not agree with them (Silverstein, 2010). In Arab countries, the same Saudi Arabia, moderate taymit theologians work diligently with their followers, so that they do not fall into the extreme network. But the probability is high and the risk persists. In 1979, during the Hajj the Al-Haram mosque was seiged by an extreme Wahhabi group led by al-Dzhuhayman'Utaybi who demanded the withdrawal of Al Saud kings and announced the true from their point of view Islamic state (Sookhdeo, 2004).

In this context, the issue of Salafi, or more correctly speaking, the Wahhabi taymit or doctrinal literature is especially acute for the RT because the system of taymit views successfully spreads through literature in print and media form. This is one of the channels to deliver information, which considerable sums were spent on. Besides the best samples of the said literaturet have been tested for years, and some of them for more than ten years in the Muslim schools of Tatarstan.

\section{Methodological Framework}

\subsection{The Objectives of the Research}

In the study, the following tasks were handled: 1) the definition of "Salafists" in the context of the general Muslim; 2) consideration of the types of followers of Salafism in Tatarstan; 3) identification of the main models of Salafi doctrinal literature published in Tatarstan; 4) theological analysis of selected samples of the said literature.

\subsection{Theoretical and Methodological Basis of the Study}

Theoretical and methodological principles accumulated in modern and historical sciences is the methodological basis of the work. System, islamic and comparative analysis are selected as the main methods and principles of the present study.

\subsection{The Basis of the Research}

Samples of Salafi doctrinal literature, which were published in Tatarstan at the beginning of the XXI century and have a circulation among local Muslims made the methodological basis of the study.

\section{Results}

\subsection{Salafi Sect in Tatarstan}

As noted by researchers Mukhametshin R. (2003) and V. Yakupov (2005), in the 1990s Islam of Salafits persuasion entered Tatarstan. In a short time the number of followers of Wahhabism increased, the sources of the latter is widely spread. The negative aspects of Islam began to appear in the territory of RT. For example, unfortunately, in some regions of Tatarstan there are young people who simply refuse to listen to the preachers, when they begin to refer to Imam Abu Hanifa and Imam al-Maturidi, traditional Muslim authorities. In this regard, the Spiritual Administration of Muslims of the Republic of Tatarstan (RT MRB) should try and work to change the situation.

It is no secret that the above-mentioned youth is a risk group, especially in an environment of strong religious illiteracy. Such young people are easy "prey" for the extreme Wahhabi preachers, that is, representatives of jihadism. Main authorities of conventional and the extreme Salafis are the same. There are only a few different interpretations and approaches to certain issues. It is clear that this situation has come about not immediately; it resulted from the years of uncontrolled intervention of representatives of non-traditional sects of Islam. It is Salafi literature that played an important role in spreading wahhabi or taymit beliefs among the Muslims of the republic. The literature of traditional sects of Islam was not competitively capable in all aspects: quantity, quality, availability and details of

The fear of the authorities and today's RT MRB is due to the fact that there are moderate and ultra taymits, and those who have taken an intermediate position between them. The ultra so-called Salafi-jihadists are now ready for the war and lead the military and subversive activities, not necessarily openly, against infidels, including Muslims, whom they consider infidels, too. The fact that those living in the territory of infidelity or of war (dar al-Kufr or Dar al-harb) are called "Harbi" and in their terms of Sharia (by law of war) they can be killed off. It is clear that this category of Salafists are few and most unpopular. There is also a trend or takfirit or neoharidzhits among extreme Salafists, which is the most radical wing of the group (Alshech, 2014). It is the proponents of such beliefs that could be implicated in the murder of the head of the education department of the RT MRB Waliullah Hazrat Yakupov and assassination attempt upon mufti of Tatarstan Ildus Hazrat Faizov in the summer of 2012 .

Those who took an intermediate position are waiting for a favorable situation for the beginning of its war or 
jihad from their point of view. They believe that now it is not the time to conduct a military jihad, and they need to prepare for it. They believe that the harm to the Muslims will be more if they perform with weapons against the existing power. At the same time they represent the most risk, a breeding ground for the extreme. Today this youth is trying to leave the country and go to Syria to join the Salafi-jihadists.

The bulk of the Salafis is classified as moderate. They are essentially a group of propaganda (da'vat), that is, they are peacefully trying to convey his teachings to others. They are very loyal towards the authorities. Most often, they try to avoid belonging to any Jamaat and group around certain authorities, theologians having taymit understanding of Sharia law. Among the latter, there are the so-called book Salafis totally apolitical and non-corrosive elements, oriented only to the call (da'vat) and education of Muslims, ready to engage in dialogue with others. Taymits of all levels have mutual accusations, criticism, labeling inter se.

This writer worked part-time in 2005, in the Council on Religious Affairs of the Cabinet of Ministers of Tatarstan, taught at Kazan madrassas "Muhammadiya" from 2002 to 2008, then worked as the dean of the theological faculty until 2011, in RIU, participated in the working committees of the Council for religions that checked the work of Tatarstan madrassas. The most alarming, we believe that the Salafi literature penetrated the system of Islamic education in the country. Analysis of information on the madrassas in Tatarstan and separate Russian Islamic University (RIU) in Kazan showed that taymization took place in almost all Islamic schools. Taymit sources in the Arabic or Russian or Tatar language were used in the educational process, mainly in the Faith lessons ('aqidah) (Almazova, 2012). Almost until 2007 in the RIU the discipline «'aqidah» was taught by Salafi textbooks.

\subsection{The Adaptations of Main Salafi Textbook (Sharh at-Tahawiyya) in Tatarstan}

The main taymit source that can be easily found in any Arabic-language library is the interpretation of the creed of the Hanafi Imam al-Tahawi made by Sheikh Ibn Abi al-al-'Izzom Azra'i al-Hanafi (d. in 798 A.H). Credo al-Tahawi itself is a source of doctrine for all Sunnis. And it has a different interpretation, and some of them were even published in Kazan before revolution. But the interpretation of Ibn Abi al-'Izza does not correspond to what is taught by the main representatives of the traditional Sunni Islam Ash'aris and maturidits, because it goes against the provisions of the author of al-Tahawi and accordingly Imam Abu Hanifa and his disciples. To be objective, we say that the dispute concerns only certain issues ('aqidah). As for the most of the other issues, particularly the sections of faith in angels, the Scripture, the prophets, the Day of Judgment, predestination, Ibn Abi al-'Izz like Ibn Taymiyyah, does not go outside Ash'aris and maturidit beliefs.

The modern interpretation of the above-mentioned publications taymit authorities themselves have reported this after they admitted that to be their main source in the field of doctrine (Ibn al-'Izz, 2006). This source is of higher degree than even the book "Book of Monotheism» («Kitab al-Tawhid») by Ibn 'Abdalvahhaba. The logic of spread of this interpretation among Hanafi Muslims is very simple. After establishhing the Russian Islamic University in Kazan in 1998, the University authorities unofficially requested by students and graduates of Tatarstan theological faculties in Saudi Arabia for help in training programs and literature. A question was raised about the main creed textbook. It was stated that Imam al-Tahawi Hanafi and Shaykh Ibn Abi al-Hanafiis 'Izz is also Hanafi. So why look for some basic source of Hanafi doctrine, as it is already there since the Middle Ages, clearly explaining the true teachings of Islam ?! Ibn Abi al-'Izz was really a Hanafi in matters of religious practice, but in matters of doctrine, according to his interpretation, he was a follower of Ibn Taymiyya. He does not mention the name of Ibn Taymiyya, as there were objective historical reasons. Official Sunni theologians then condemned the idea of Ibn Taymiyya and his few followers. Taymit scientists themselves have confirmed this finding in the interpretation extracts from the books of Ibn Taymiyya (Ibn al-'Izz, 2006). Of course, there are issues over the Hanafism of Ibn Abi al-'Izza because of some of his treatises, especially criticism of the famous Hanafi source "al-Hidayat." This phenomenon, when a theologian is Hanafi in matters of religious practice, and not Hanafi (maturidit) in matters of faith, is known to science. For example, the prominent linguist and commentator of the Quran Hanafi Imam al-Zamakhshari, was mu'tazilite, a representative of a heretical school of Islamic theology (Shagaviev, 2015).

Teaching Islamic Faith in the original by this book is difficult, because of the language, style, specific terminology and the order of presentation. It needs special training. Therefore, there are many modern tanscriptions and adaptations of this medieval source, so that less trained religious teachers and students of madrassas could use them. Therefore not only copies of the original work by Ibn Abi al-'Izza, but modern processed versions and summaries appeared in the libraries of Tatar madrassas. One of them in Arabic, was published in the RIU (Kazan) as a guide in 2002. It was a re-release of the original Saudi of 1990 (al-Sawi, n.d.). The issuance to the RIU can be determined only on the cover by the logo and the name of the RIU in Arabic, 
English, Russian and Tatar languages.

At the same time the other shorter revised version compiled by a doctor of theology Muhammad al-Humayyis was published twice in Kazan in the original language. One edition was published by "Tatarstan Diniya Nazaraty" organization, that is, by RT MRB of that period, at the expense of the Bahraini Charitable Organization «Jam'iyyat al-tarbiyya al - islamiyya» also as a benefit for madrassa students. In the upper left corner of the cover "gift" is written in Arabic. It means that this book was distributed free of charge. The review by RT MRB in the Tatar language is given inside the book. It says that, the doctrine according to the sense of Imam Abu Hanifa is set forth in the book approved by the Spiritual Directorate of Tatarstan, and that it can be used as a textbook for senior students of madrassas.The review was signed on behalf of the Kazan local imam, who was qazy (qadhi) in Kazan (al-Khumayyis, n.d) at the time of publication of the book. We believe that the imam could not even guess of the Salafi nature of the book. The second edition differs only by its cover, which Russian Islamic University was already listed.

Then the translations into Russian and Tatar languages came. In 2004, RIU published an adapted interpretation in the Tatar language, authored by Muhammad al-Sawi, 356 pages (as-Savi, 2004). In our opinion, this is the most detailed book on Islamic teachings in the Tatar language at the moment. It is not known whether the Russian translation of the book was published, but he had circulated electronically.

A few years ago in the city of Nizhnekamsk Russian translation of another adaptation of the above interpretation of Ibn Abi al-'Izza was again published with the circulation of 3,000 copies (al'-Khanafi, 2011). This translation indicated that it was an ordered arrangement made by Saudi theologian Salih ibn Abderrahman. The Russian translation of the book is filled with lots of theological tradition inconsistencies adopted from the Tatarstan Muslims and Hanafi- maturidit in general. At that there are methodological shortcomings in the material supply. For example, an incomplete version of the hadith is given: "I was ordered to fight with (these) people up until they testify that there is no god but Allah and that Muhammad is the Messenger of Allah ...". There is another version in the footnote where the hadith continues, "and will not perform the prayers and pay the zakat, and if they do that, then protect me from their lives and their property ..." until the end of the hadith (al'-Khanafi, 2011). Why is this hadith presented in such interpretation to a Russian reader? Why did not an experienced translator put a note or comment next, which he gives in large quantities in other parts of the book. Perhaps this hadith sounds fine in Saudi Arabia without comment, but under Russian conditions it is impossible to leave it without explanation.

In the preface of the book the compiler tells the biography of Ibn Abi al-'Izza and proves that he was not a strict follower of the Hanafi, and makes the assumption that he, as a teacher in the Hanafi madrassa could give lessons on the views of other schools, choosing the closest match to the text of the Quran and Sunnah (al'-Khanafi, 2011). It is obvious that this version is written specifically for the Salafis, rather than the traditional Sunni-Hanafi.

This book was provided with reviews of one of the former imams of a very famous and important Kazan mosque "Kul Sharif". The review stated: "... it took about twenty years since we have the opportunity to join the roots, go back to our culture and to practice the religion of our ancestors. Therefore, it is very important for of the Russian-speaking reader the emergence of this important book, with a very detailed and broad interpretation. It is noteworthy that even before the revolution "Muhammadiya" madrassa students studied this work, printed by Galimzhan al-Baroudi at his own expense » (al'-Khanafi, 2011). The misunderstanding consists in the following: the imam-hatyyb speaks about Imam al-Tahawi's Creed, that his works were even published in pre-revolutionary "Muhammadiya" madrassa, but sentences are arranged in its recommendation so that the reader might think that the rector of "Muhammadiya" Galimzhan al-Baroudi published Ibn Abi al-'Izza's interpretation for their students! The fact is that the edition of Kazan interpretation of Hanafi scholar Siradzhaddin al-Hindi was used in the pre-revolutionary madrassa. One of the publications is exhibited at the museum of the said mosque. We do not know whether the Tatar imam understood the ambiguity of his replica. However, judging from the reviews, it still endorses this interpretation and considers it relevant. The question arises whether he got acquainted with this interpretation, or relied on the knowledge that he had received within the years of training in Saudi Arabia? In 2011, the book was banned by RT MRB for sale and use in the subordinate mosques and madrassas, and the famous imam was reprimanded. By the way, in 2011 in the RT MRB RT there have been major changes in the lineup, President (Mufti) was replaced.

\subsection{The Salafi Adaptation of Abu Hanifah's al-Fiqh al-akbar}

We know the example of the publication of other known source of the Hanafi doctrine in Tatarstan with a brief interpretation of the Salafi movement (Minleakhmat, 2012). This source is called «al-Fiqh al-akbar» and mothered on to the most Imam Abu Hanifa. A certain author, who identified himself as Mullah Niyazetdin 
Minleehmet al-Hanafi, apparently also from Nizhnekamsk, published this work in the Tatar language, providing it with a brief explanation. Judging by nisba or tahallus the author or compiler of explanations declares himself Hanafi. But from the very first pages, he explains the concept of monotheism not in the way, as is done in traditional Hanafi interpretation. Namely, it gives a threefold classification of monotheism (Minleakhmat, 2012), introduced by Sheikh Ibn Taymiyyah which has become traditional for the doctrinal literature of Salafi persuasion. In addition, without detailed consideration of the interpretation the compiler accuses Abu Hanifa of the contradictions to the majority of Sunnis on the issue of the definition of faith (Minleakhmat, 2012).

\subsection{The Adaptation of Ibn 'Abd al-Wahhab's Kitab al-tawhid}

Another illustrative example of the Salafi doctrinal literature in Tatarstan is the book published in 2004 in the Tatar language (Galavetdin, 2004), which in Russian can be called "Monotheism" by the imam-hatyyb of the mosque, "Tauba"in Naberezhnye Chelny.

The book is labelled by MRB RT Ulema Council and there is a preface with the blessing of the MRB RT chief Kazi. Most likely, the late and much respected imam (ex-qadhi) in Tatarstan, has not read the book and just put his signature, although it is also possible that his name was simply used. It is known that the past management of the RT MRB formally approached such matters. We also know that at the time of the Ulema Council has not actually worked and practically not going to.

In the same year the book went on sale in bookstores, and its circulation was 2,000 copies. Indeed, the book explains the concept of monotheism and the related provisions of the Sharia. However, the structure of the book coincides with that of the book of the same name «Kitab al-Tawhid» («The Book of Monotheism") by Shaykh Muhammad ibn 'Abdalvahhab ibn Suleiman al-Tamimi, the founder of the Wahhabi current of Islam. Even the names of the sections and their order are the same. Tatar author missed only one partition (the 50th) of this book, so instead of 67 there are only 66 chapters in his book. All the verses and hadiths are presented in the book of the Arab author, except for those of the 50th chapter. However, the Tatar author or compiler did not mention the most important source of his work. Most likely this was done intentionally, because the name of Sheikh Ibn 'Abdalvahhab raises some concerns among local Muslims.

The addition to the text from the "Book of Monotheism" Ibn 'Abdalvahhaba is basically a translation of one of the comments on this book, designed as a catechism. And there are a lot of comments, many of them published in Saudi Arabia. If we look at the questions and answers presented in the book of the Tatar author, it turns out that they correspond to the meaning of those of from the book of the Saudi Wahhabi author Hafiz al-Hakami "200 questions on doctrine of Islam." This book is also published in Russian in Moscow in 2000 (edition of "Ibrahim Al Ibrahim"), and in the Tatar language, again in the RIU in Kazan in 2003 (Khakami, 2003). Thus, the author of the Naberezhnyie Chelny dubbed what has been said and written by representatives of the Wahhabi doctrine the Tatar language.

In 2014 we found a book in Muslim bookshops under the title «Iman dareslare» (that is, lessons about faith) without any output. By its content it appeard to be the above-mentioned book by Idris Galevetdin. Thus, supporters of the Salafi creed continue distributing their literature under any names.

The author of these lines in 2005 saw the "Book of Monotheism"by Ibn 'Abdalvahhab in Tatar in Arabic script on sale in one of the central mosque in the of Kazan The book was published in Saudi Arabia. The spread of such literature is difficult to control, and methods of the ban, in our opinion, is unlikely to be effective in the era of widespread Internet.

\subsection{Another Kind of Salafi Books in Tatarstan}

On the other hand there is another layer of literature, to some extent, popular among local Muslims, which is Salafi one only on the basis of authorship or use the methodology of the Salafis, for example, in the Hadithology. In view of the same literature subjects and genre common for all Sunnis it does not go into conflict with an understanding of traditional sects in Islam.

We are talking about books, which forcuse on the moral problems of society, or are a compilation of texts of prayers for particular occasions. A series of the books were published by the aforementioned Idris Galyavetdin. We can recall, as an example, the translations of book "Fortress of the Muslim" («Hisn al-muslim») by Sa'id al-Qahtani into Russian and Tatar.

The representatives MRB RT impose no obstacles in the spread of such books, and sometimes, if the work is known and recognized in the Sunni world, on the contrary, they take part in its canonical legalization. Recently a famous work "The Book of the soul» («Kitab al-Ruh») by Ibn al-Qayyim (al-Djavziya, 2013), a student of Sheikh Ibn Taymiyya was published in Kazan. The book has a'review of MRB RT signed by muftii of Tatarstan 
Kamil Samigullin. Thus, representatives of the official Muslim clergy is do not practice indiscriminate ban of books. First of all, the works of Salafi authors on specific issues of "aqidah and fiqh" fall under the criticism. If other issues are handled, the relation to these books is usually neutral.

It is clear that Salafi books printed outside the country had and have circulated in Tatarstan, the latter being published in large editions. It is a question of a separate study. Large flow of such literature is associated with the trends seen across the globe. To some extent, this reminds globalization that occurs among the Muslims. Now, this literature is distributed through the Internet.

\section{Discussions}

The problem of Salafism in Tatarstan was considered by a number of researchers in different aspects. However, I would like to highlight the following works.

R.M. Mukhametshin (2003) researched the influence of the Wahhabi Muslims of Tatarstan in the framework of the analysis of informal forms of Islam, revealing the basic laws of Islam and the functioning of its institutions in the Republic of Tatarstan and Tatar society in the XX century. This study helps to understand how the penetration Salafi trends in these regions happened.

V.M. Yakupov (2005) particularized the problem of Wahhabism in the Tatar society of the 1990s. Considering the existence of informal forms of Islam, the author raises the question of the spread of Wahhabism in Tatarstan and shows the cause and scope of such an extension in the context of the revival Hanafi amongf the Tatars.

L.I. Almazova (2012) examined the Salafi factor in connection with the study of the state of the secondary Muslim education in Tatarstan at this stage, by 2012. The annexes to this paper show the lists of textbooks madrassas in various Islamic disciplines that helped us in the writing this article.

Previous studies have not addressed the issue of classification of Salafis in Tatarstan, as well as has not been studied the aspect of Salafi literature that has been done in our study.

\section{Conclusions}

Thus, the Salafi literature was quite successfully published and distributed in Tatarstan. The article discusses the most striking examples of this. And now, not rare buyers will find some instances of such literature in the stores. We can assume that many RT Muslims studied doctrine according to these books. At least, we know that the Islamic fait was taught with the use of these textbooks in the local madrassas. At that the books, which describe the Muslim rituals such as prayer are not meant. In this area Salafi element somewhere open, and somewhere in a veiled form also appear. Circulation of such literature among local Muslims raises concerns, because the factor of informal forms of Islam, such as Salafism is exacerbating in the region, the modern authorities of which are abroad outside of Tatarstan. The spread of Salafism in the region can eventually lead to the emergence of radical branches of Islam, and probably hazard safety in the country.

In view of the course taken in the MRB RT to Hanafi confession in matters of faith and fiqh, and traditional character of this direction for the local Muslims the representatives of the traditional Muslims face the problem of saturation of the local book market with works of Hanafi (maturidit) authors. In the first place there must be at least a balance in this area, because in Tatarstan the prevalence of books of Salafi authors quantitively and qualitatively can not be considered normal.

\section{Acknowledgement}

The work is performed according to the Russian Government Program of Competitive Growth of Kazan Federal University.

\section{References}

al'-Buti, M. S. R. (2008). Salafiya (I. Popov, Trans). Moscow.

al'-Khanafi, A. bin Abi al-'Izz. (2011). Kommentarii $k$ veroucheniiu imama At-Takhavi (uporiadochennoe izlozhenie) (I. Sorokoumova, Trans.). Nizhnekamsk.

al-Buti, M. S. R. (2008). Mashurat ijtima 'iyya. Damascus.

al-Khumayyis, M. ibn ‘Abd ar-Rahman. (n.d.). Sharh at-Tahawiyya al-muyassar. Riyadh.

Almazova, L. I., \& Shangaraev, R. R. (2012). Analiz sostoianiia i perspektivy razvitiia srednego professionalnogo musulmanskogo obrazovaniia v Respublike Tatarstan. Musulmanskoe obrazovanie $v$ Tatarstane: istoriia, sovremennoe sostoianie i innovatsionnye protsessy: tsikl statey (pp.33-74). Kazan.

al-Sawi, M. S. M. (n.d.). Tahdhib sharh at-Tahawiyya. Kazan. 
Alshech, E. (2014). The Doctrinal Crisis within the Salafi-Jihadi Ranks and the Emergence of Neo-Takfirism. A Historical and Doctrinal Analysis. Islamic Law and Society, 21, 419-452. http://dx.doi.org/10.1163/15685195-00214p04

as-Savi, M. S. M. (2004). Tahawi gakydasenen anlatmasy. Ed. N. Ibragimov, translated by I. Sitdikov, Kazan.

Galavetdin, I. (2004). Allahyny - ber dip tany. Kazan.

Ibn al-'Izz, 'A. (2006). Sharh 'aqidat at-Tahawi. Takhrij M. Nasir al-Din al-Albani. Beirut.

Khakami, H. bine Akhmat. (2003). Dini taglimat. Kazan.

Minleakhmat, al-Khanafi, N. (2013). "al-Fikh al-Akbar" kitabyna kyskacha anlatma. Tuban Kama. Nizhnekamsk.

Mukhametshin, R. M. (2003). Tatary i islam v XX veke. Kazan.

Qadhi Ya. (2013). On Salafi Islam. Retrieved from http://muslimmatters.org/

Shagaviev, D. A. (2015). Islamskiye techeniya i gruppy. Uchebnoe posobie. Kazan.

Silverstein, A. J. (2010). Islamic History: a very short introduction. New York. http://dx.doi.org/10.1093/actrade/9780199545728.001.0001

Sookhdeo, P. (2004). Understanding Islamic Terrorism: Islamic Doctrine of War. London.

Yakupov, V. M. (2005). Islam v Tatarstane v 1990-e gody. Kazan.

\section{Copyrights}

Copyright for this article is retained by the author(s), with first publication rights granted to the journal.

This is an open-access article distributed under the terms and conditions of the Creative Commons Attribution license (http://creativecommons.org/licenses/by/3.0/). 